\title{
Historical flash floods retromodelling in the Ondara River in Tàrrega (NE Iberian Peninsula)
}

\author{
J. C. Balasch ${ }^{1}$, J. L. Ruiz-Bellet ${ }^{1}$, and J. Tuset ${ }^{2,3}$ \\ ${ }^{1}$ Department of Environment and Soil Sciences, University of Lleida, Spain \\ ${ }^{2}$ Forest Science Centre of Catalonia, Solsona, Spain \\ ${ }^{3}$ RIUS Fluvial Dynamics Research Group, UdL, Spain
}

Received: 15 April 2011 - Revised: 12 August 2011 - Accepted: 7 October 2011 - Published: 21 December 2011

\begin{abstract}
Flash floods in the Ondara River have caused many fatalities and damages in the town of Tàrrega in the last $400 \mathrm{yr}$. Unfortunately, no flow records are available.

However, floods can sometimes be reconstructed thanks to available historical information: limnimarks, written accounts and archaeological surveys. Indeed, from these data and using the retromodelling method on three different scenarios to take into account morphology changes, the peak flows of the seven greatest floods occurred in Tàrrega since the 17 th century were estimated.

The results showed that the heaviest flood's specific peak flow $\left(10.7 \mathrm{~m}^{3} \mathrm{~s}^{-1} \mathrm{~km}^{-2}\right)$ ranks among the highest ever modelled or measured in similar-sized catchments in the Western Mediterranean region. The results pointed out, as well, that the changes in channel's morphology (mainly, the disappearance of a mediaeval bridge under sediment) caused by one of the floods increased the hydraulic capacity of a crucial crosssection. All this resulted in modest floods invading the town less often, but with much faster and, thus, more destructive flows.
\end{abstract}

A preliminary estimation of the results' uncertainty was $4 \%$ for great floods and $18 \%$ for modest floods.

The reconstructed peak flows will be introduced in a database for a future use in climatic and hydrological studies.

\section{Introduction}

Flash floods are a common hydrological event in the small and medium-sized catchments located in the Mediterranean coastal fringe of Catalonia, in NE Iberian Peninsula (Llasat et al., 2003; Gaume et al., 2009). Nevertheless, this torrential behaviour is also known to catchments located inland,

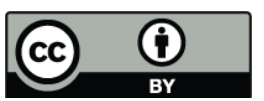

Correspondence to: J. C. Balasch (cbalasch@macs.udl.cat) specifically to those enclosed in the Ebro River basin having their headwaters on the coastal ranges, the water divide between the coastal and the inland catchments. Indeed, in these catchments, flash floods occur frequently - usually caused by autumn convective rainstorms coming from the Mediterranean Sea - and have historically caused fatalities and damages.

However, flash floods have not been studied in these catchments so far. Besides, historical floods in the Iberian Peninsula have usually been used to find climatic temporal trends (Barriendos and Martín-Vide, 1998; Llasat et al. 2005; Benito et al., 2008) and, except for floods occurred in large basins (Benito et al., 2003; Thorndycraft et al., 2006; Ortega and Garzón, 2009), rarely have they been hydraulically reconstructed.

Thus, our research focuses on historical flash-floods' reconstruction in $200-500 \mathrm{~km}^{2}$, westward-flowing catchments located in the eastern-most fringe of the Ebro River basin.

Among them, we have chosen the Ondara River's catchment as the paradigm to study flood reconstruction because a lot of information about historical floods can be found there, both as flood marks, also called limnimarks, and as documents: written accounts found in archives (Salvadó, 1875; Iglesies, 1971; Segarra, 1987; Farré, 2008), press chronicles and photographs (Coma, 1990).

A reason for this abundance of information might have been the great magnitude of the damages caused by the floods, due to the Ondara's catchment having historically been a very populated area, with important towns such as Tàrrega and Cervera (16500 and 9300 inhabitants respectively, in 2009).

Thus, according to written and epigraphic documents, the Ondara River has flash-flooded the town of Tàrrega at least seven times since the early 17 th century: in 1615,1644 , $1783,1842,1874,1930$ and 1989 , sometimes causing a great number of fatalities: more than 300 in 1644 and about 150 in 1874.

Published by Copernicus Publications on behalf of the European Geosciences Union. 


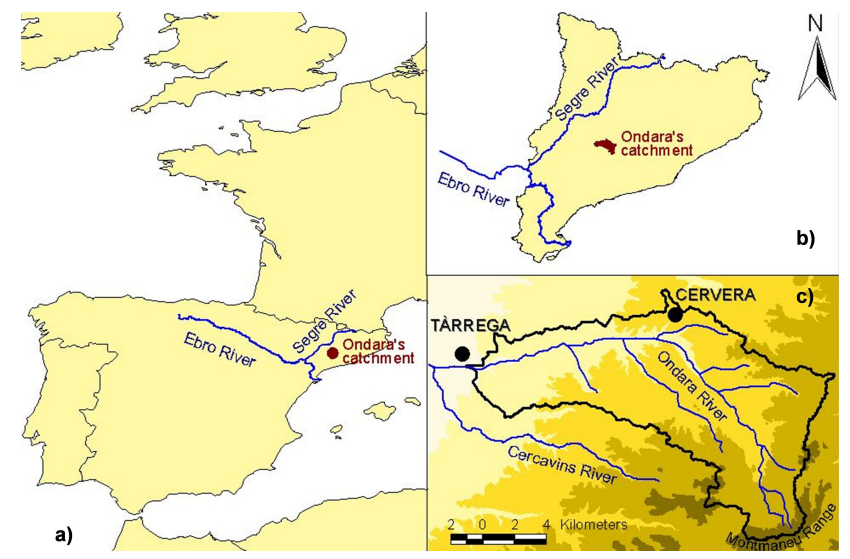

Fig. 1. Location of the Ondara River's catchment within the Iberian Peninsula (a) and within Catalonia (b), and map of the catchment itself with the location of the town of Tàrrega (c).

Besides specific information about the floods, hydraulic modelling requires data about the channel's and floodplain's morphology and roughness. Fortunately, a lot of information about the evolution of these features in the Ondara River is available thanks to the efforts of local archaeologists and historians.

In spite of this abundance of information, it has never been used to hydraulically or hydrologically reconstruct those events; with one exception: 1874 Santa Tecla's flood has only recently been modelled in order to quantify its peak flow and the rainstorm that caused it (Balasch et al., 2010a, b).

Therefore, the objectives of this paper were to find and process all the available information in order to calculate 1615, 1644, 1783, 1842, 1930 and 1989 floods' peak flows and improve the previously calculated 1874 flood's peak flow.

\section{Study framework}

\subsection{Catchment}

The Ondara River is a left-side tributary of the downstream stretch of the Segre River, which is, at its turn, the main tributary of the Ebro River (Fig. 1); however, before reaching the Segre, the Ondara River's water flows into a large alluvial fan just downstream Tàrrega. When it arrives at Tàrrega, at a height of $362 \mathrm{~m}$ above sea level, the Ondara has a length of $28.6 \mathrm{~km}$ and an average slope of $1.5 \%$.

Its catchment is $150 \mathrm{~km}^{2}$ and has an east-west orientation, its headwaters lying on the Central Catalan Depression's monoclinal relieves, with the highest point at Coll de la Creu del Vent, in Montmaneu Range (804 m). Cereal unirrigated crops cover $85 \%$ of the catchment's area, whereas forest and uncultured soil cover $13 \%$ and urban soil, $2 \%$.

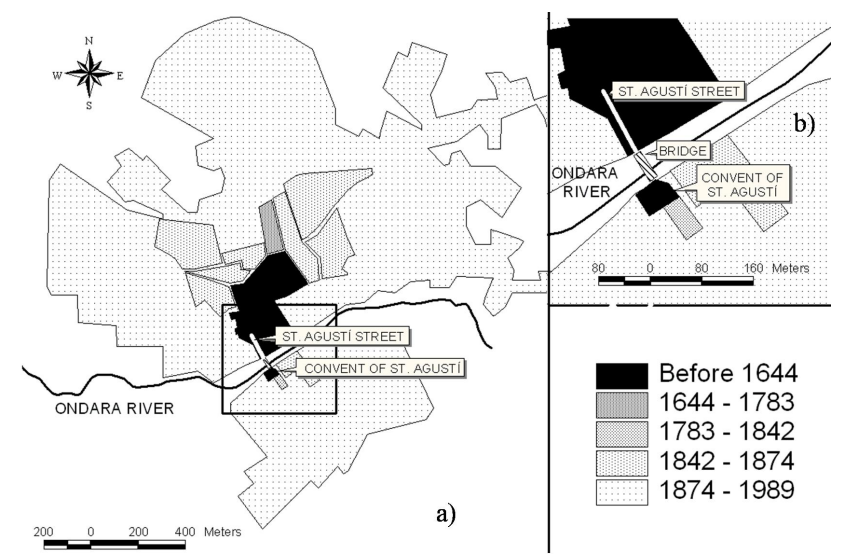

Fig. 2. Tàrrega's urbanized area evolution since the 17th century (a) and detail of Sant Agustí Street area (b).

Although there has never been any flow gauging station on the Ondara River, its modest average flow at the end of the alluvial fan could be estimated through water resources modelling (CHE, 1996): $0.5 \mathrm{~m}^{3} \mathrm{~s}^{-1}$. However, the alluvial fan's flow is greatly increased by the seepage from irrigated fields; thus, the share of water coming from the Ondara must be smaller, a good estimation of its average flow in Tàrrega being $0.1 \mathrm{~m}^{3} \mathrm{~s}^{-1}$ or less.

Ondara's hydrological regime, not regulated by any hydraulic structure, shows a high-water period around May and long low-water periods, a consequence of the continental Mediterranean climate (Köppen Csa) of the catchment, which has an annual mean rainfall of $450 \mathrm{~mm}$ with a variation coefficient of $20 \%$. In any case, autumn overflowing flash floods are not rare, occurring about three or four times per century, according to the most complete record compiled by Coma (1990) and Espinagosa et al. (1996). Severe flash floods, caused by great rainstorms, often occur simultaneously in Ondara and its adjoining catchments: Sió and Corb.

Certainly, severe rainstorms are common; this can be partially explained by the regional relief, which triggers storms in two ways: stopping weather fronts that come from the Mediterranean Sea and contributing to the development of convective rainstorms during summer and early autumn. All this results in an eastward rainfall gradient, because weather fronts come from the east and because the highest lands, where convective rainstorms are more likely to form, are in the eastern part of the catchment.

\subsection{Evolution of the town's and the floodplain's morphology}

The knowledge of the channel's and the floodplain's morphology is essential in hydraulic modelling (see Methods). However, this morphology can change greatly in $400 \mathrm{yr}$, especially in urban areas (Fig. 2). 


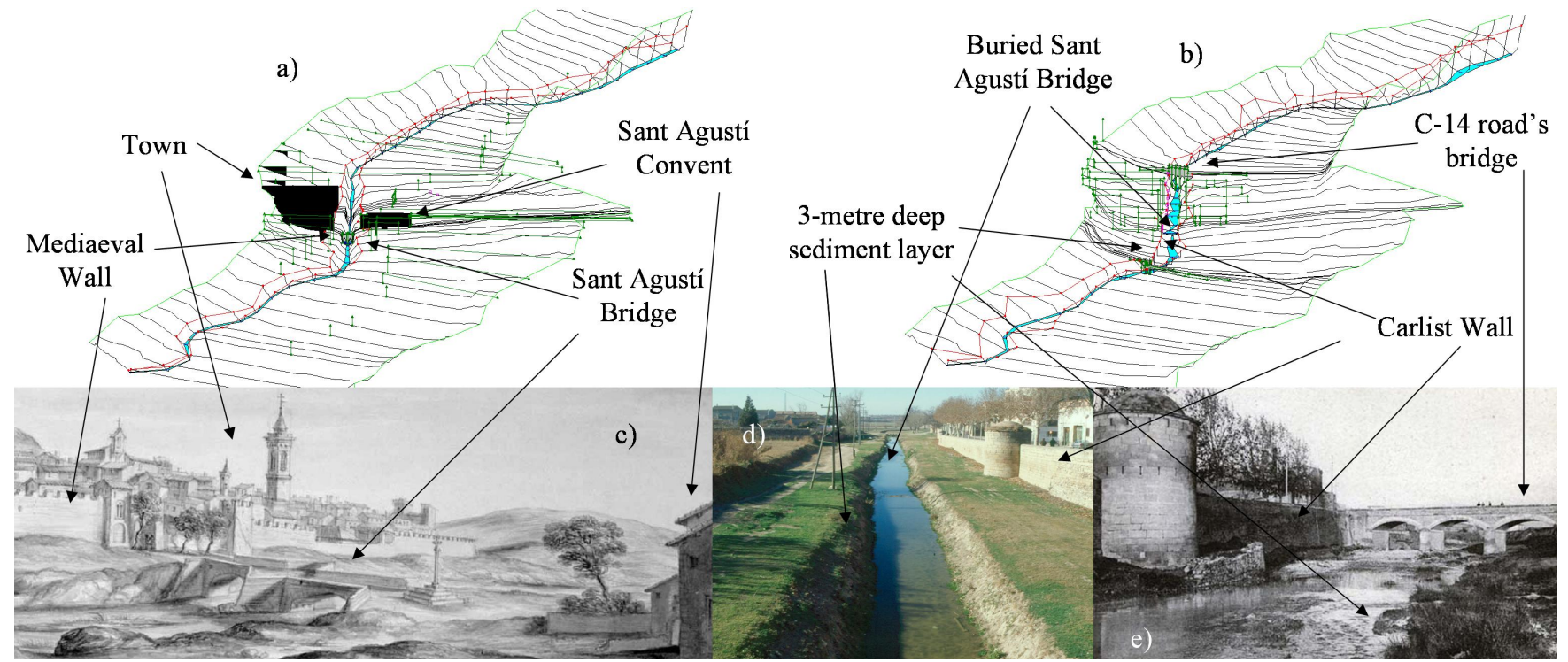

Fig. 3. Two of the three morphology scenarios used in the modelling: scenario A (a) and scenario C (b) including the 53 cross-sections and their main morphology features, illustrated by: Pier Maria Baldi's 1668 drawing (c), a 2007 downstream view from the C-14 road's bridge (d), and a 1905-1915 upstream view of the Ondara River in Tàrrega and the C-14 road's bridge (e).

Thus, in order to reconstruct as faithfully as possible the floodplain's and channel's morphology at the time of each studied flood - including the main obstacles to the water flow, i.e. houses, walls, bridges, streets - many sources of historical information were used: archaeological surveys, written accounts (Salvadó, 1875; Segarra, 1987; Farré, 2008), antique town maps (from the local archives: Urgell County Archive), the 1668 artistic drawing by Italian artist Pier Maria Baldi and photographs.

Tàrrega was founded in the 11th century, between the right bank of the Ondara River and the slopes of Sant Eloi's Hill. Both its population and its urbanized area remained more or less unchanged until the railway opening in 1860 boosted the growth of the town, which rose from 4000 inhabitants up to 8000 inhabitants in 1930. This growth continued throughout the 20th century, but only recently the town has spread onto the river's left bank and has reached a population of 16500 .

There is proof of at least one major change in the floodplain's and channel's morphology in the last $400 \mathrm{yr}$ : a 3-mdeep sediment layer transported by the 1874 flood and discovered by recent archaeological surveys.

Besides this natural geomorphological change, the presence or absence of several man-made features in the immediate vicinity of the river have greatly modified the floodplain's and the channel's morphology in the last $400 \mathrm{yr}$ : Sant Agustí's Convent and slum on the left bank, Sant Agustí Bridge, two walls alongside the right bank: a mediaeval one and a modern one, and the bridges of the roads $\mathrm{C}-14$ and L-2021 (Fig. 3). More precisely:
1. Sant Agustí's Convent was built on the left bank of the river in 1322, destroyed by the 1644 flood and rebuilt immediately afterwards, and definitely destroyed by the 1874 flood. The stones of the ruined monastery were used to build Sant Agustí slum, which is still in place.

2. Sant Agustí Bridge was built circa 1340 and connected the eponymous street with the eponymous convent on the left bank; it was damaged by floods and afterwards reconstructed in 1615, 1644 and 1842; finally, it was buried in a 3-m-deep sediment layer deposited by the 1874 flood.

3. The mediaeval wall was built in $1360-1370$, more to protect the town against armed attacks than against floods. It was severely damaged by the 1644 and 1874 floods; finally it was buried in the 3-m-deep sediment layer that covered Sant Agustí Bridge.

4. The modern wall - known as the Carlist Wall - was built in 1875 as a defensive response to the 1874 flood and is still in place, a little bit closer to the river axe than the mediaeval wall and lying on the 3-m-deep sediment layer.

5. C-14 road's bridge was built in the early 20 th century, and is still in place.

6. LV-2021 road's bridge was built in the early 20th century, and is still in place.

In the 1990s, the Ondara River's floodplain at Tàrrega was channelled by building a wall along the left bank; this enabled a heavy urbanization of the area behind that new wall. 


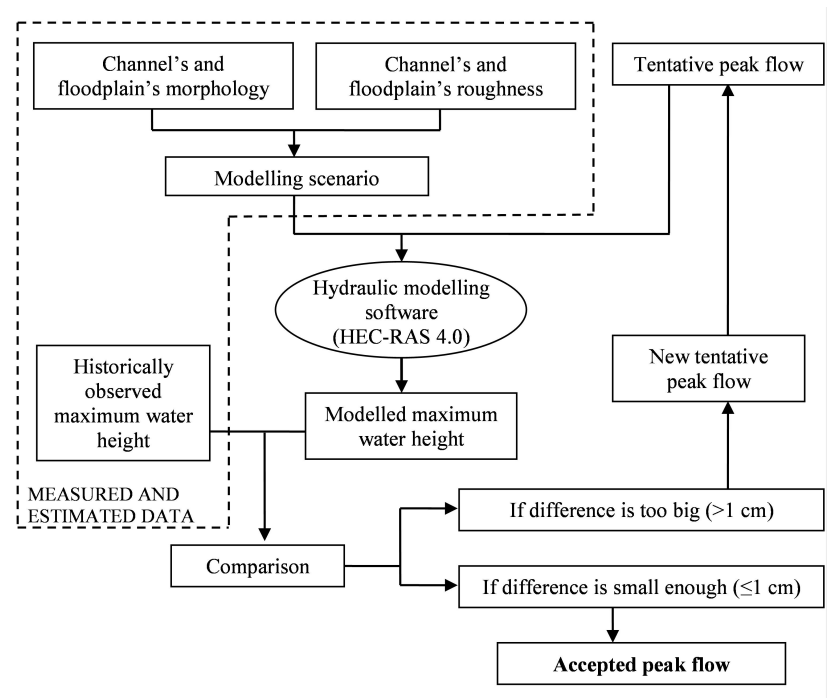

Fig. 4. Iterative procedure of the retromodelling method applied in each reconstructed flood.

Moreover, in early 2000s, the floodplain between the two walls was turned into an urban park and a footbridge was built just over the nowadays buried Sant Agustí's Bridge.

\subsection{Historical floods}

An historical flood is a flooding event not measured by instruments, but recorded in different historical information sources: limnimarks, written accounts, photographs. Sometimes, there is enough information, both in quality and in quantity, to allow a reliable hydraulic reconstruction of the historical floods' peak flows.

The basic piece of information needed in historical floods' reconstruction is maximum water height. This datum can be obtained from a limnimark (a commemorative plaque or a carving on a wall which points out the maximum height reached by one particular flood), a written account or a photograph; sometimes, the latter two can even inform of the water height at times other than the peak time, thus allowing the estimation of the flood's evolution over time, that is, of its approximate hydrograph. Moreover, written accounts can provide some details required for the reconstruction of the rainstorm hyetograph - such as the rainstorm's starting and ending times and the rain occurrence in previous days.

So far, we have found seven historical floods in the Ondara in Tàrrega with enough information to reconstruct their peak flows: three maximum water heights given by limnimarks $(1644,1783$ and 1874) and four by written accounts (1615, 1842, 1930 and 1989).

Two of them stand out due to their magnitude and the damages they caused: 1644 and 1874, both occurred at night, which explains the great number of deaths (more than 300 and 150, respectively). Besides, there is a lot of

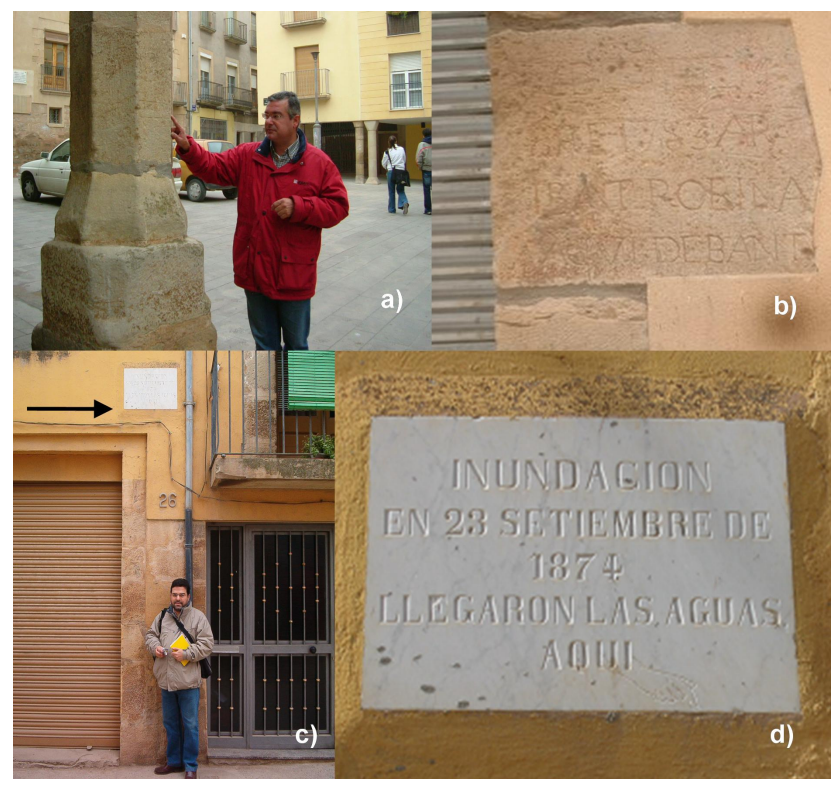

Fig. 5. Three of the five limnimarks found: (a) carving on a column at Sant Antoni Square marking the 1644 flood's maximum water height (observation 2 in Fig. 6), (b) sandstone plaque at Sant Agustí Street corresponding to the 1783 flood (observation 3 in Fig. 6), (c) marble plaque (marked by an arrow) at Sant Agustí Street corresponding to the 1874 flood (observation 5a in Fig. 6) and (d) detail of that plaque.

information about the 1874 flood, and that is why we chose it as the paradigm to start historical flood reconstruction in the area, having so far successfully estimated its hydrograph and hyetograph (Tuset, 2007; Balasch et al., 2010b).

Summarized information about the seven greatest historical floods found in Tàrrega is gathered in Table 1, along with the sources of information that report them and the most conspicuous morphology features at the time of each flood.

\section{Methods}

Depending on the available information, the hydraulic reconstruction of a historical flood can have different types of results: from just the peak flow value to the entire hydrograph.

In this case, hydrological and morphological information of the seven studied floods (the only seven known to us that flooded the town since the 17th century), which was gathered from multiple historical and archaeological sources, only allowed peak flow estimations.

We calculated these seven peak flows using the HEC-RAS 4.0 (USACE, 2008) hydraulic modelling software on onedimensional, gradually varied, steady, sub-critical flow. Actually, this software calculates water height from a flow value; hence, we applied it iteratively, trying tentative peak flows until the difference between the modelled and the historically observed water heights was smaller than $1 \mathrm{~cm}$ 
Table 1. Summary of the information about the seven studied floods, their nine historically observed water height records, and the major morphology features present at the time of each flood.

\begin{tabular}{|c|c|c|c|c|c|c|c|c|c|}
\hline Year & 1615 & 1644 & 1783 & 1842 & \multicolumn{3}{|c|}{1874} & 1930 & 1989 \\
\hline Date & 25 July & 17 September & 17 September & 25 August & \multicolumn{3}{|c|}{23 September } & 19 October & 28 October \\
\hline Popular name & Sant Jaume's flood & - & - & $\begin{array}{l}\text { Sant Bar- } \\
\text { tomeu's flood }\end{array}$ & \multicolumn{3}{|c|}{ Santa Tecla's flood } & Sant Lluc's flood & - \\
\hline Fatalities & 0 & $>300$ & 0 & 0 & \multicolumn{3}{|c|}{150} & 0 & 1 \\
\hline $\begin{array}{l}\text { Historically } \\
\text { observed water } \\
\text { height (m a.s.l.) }\end{array}$ & 366.0 & 368.39 & 364.91 & 363.5 & 367.26 & 368.30 & 369.08 & 363.4 & 363.3 \\
\hline $\begin{array}{l}\text { Location of the ob- } \\
\text { servation (Fig. 6) }\end{array}$ & 1 & 2 & 3 & 4 & $5 \mathrm{a}$ & $5 b$ & $5 \mathrm{c}$ & 6 & 7 \\
\hline Observation's record & $\operatorname{ACUR}(1621)^{1}$ & $\begin{array}{l}\text { Carving in a } \\
\text { column at Sant } \\
\text { Antoni Square }\end{array}$ & $\begin{array}{l}\text { Stone plaque } \\
\text { at } \\
\text { Sant Agustí } \\
\text { Street }\end{array}$ & Salvadó (1875) & $\begin{array}{l}\text { Marble } \\
\text { plaque at } \\
\text { Sant } \\
\text { Agustí } \\
\text { Street }\end{array}$ & $\begin{array}{l}\text { Marble } \\
\text { plaque } \\
\text { at Font } \\
\text { Street }\end{array}$ & $\begin{array}{l}\begin{array}{l}\text { Marble } \\
\text { plaque at }\end{array} \\
\text { Piques } \\
\text { Street }\end{array}$ & Local press ${ }^{3}$ & Local press ${ }^{4}$ \\
\hline Type of record & Written account & Limnimark & Limnimark & $\begin{array}{l}\text { Written } \\
\text { account }\end{array}$ & Limnimark & k Limnimark & Limnimark & Written account & $\begin{array}{l}\text { Written } \\
\text { account }\end{array}$ \\
\hline $\begin{array}{l}\text { Other information } \\
\text { sources }\end{array}$ & - & $\begin{array}{l}\text { Parets }(1891)^{2} \\
\text { and } \\
\text { Salvadó (1875) }\end{array}$ & Salvadó (1875) & - & \multicolumn{3}{|c|}{ Salvadó (1875) and Iglesies (1971) } & - & - \\
\hline \multirow{5}{*}{ Morphology features } & \multicolumn{4}{|c|}{ Sant Agustí Bridge } & \multicolumn{5}{|c|}{ 3-m-deep sediment layer } \\
\hline & \multicolumn{4}{|c|}{ Mediaeval Wall } & \multirow{2}{*}{\multicolumn{3}{|c|}{-}} & \multicolumn{2}{|c|}{ Carlist Wall } \\
\hline & \multicolumn{4}{|c|}{ Sant Agustí Convent } & & & & \multicolumn{2}{|c|}{ Sant Agustî's slum } \\
\hline & \multicolumn{7}{|c|}{-} & \multicolumn{2}{|c|}{ C-14 road's bridge } \\
\hline & \multicolumn{7}{|c|}{-} & \multicolumn{2}{|c|}{ LV-2021 road's bridge } \\
\hline
\end{tabular}

${ }^{1}$ Found in Segarra (1987) and Farré (2008); ${ }^{2}$ found in Vila (1998); ${ }^{3}$ reported by Tàrrega's Regional Museum's director (Anonymous, 1930); ${ }^{4}$ Castellà and Miranda (1989).

(Fig. 4). This method is known as retromodelling and its accuracy has been successfully tested by Lang et al. (2004), Naulet et al. (2005) and Remo and Pinter (2007).

We applied the retromodelling method separately for each of the seven studied floods along a $2700 \mathrm{~m}$ long reach of the Ondara River by the town of Tàrrega. In order to do that, we first measured and estimated the required input data: historically observed maximum water height and the channel's and floodplain's morphology and roughness.

\subsection{Historically observed maximum water height}

Historically observed maximum water height above sea level was acquired either directly from limnimarks, or indirectly from written accounts. Whichever the case, this height was measured with topographic equipment and its reliability was assessed with source analysis methods (Bayliss and Reed, 2001) and hermeneutical techniques.

When a limnimark was available, the maximum water height reached by the flood was directly marked either by a line carved on a stone column (1644 flood mark) or by the lower edge of a commemorative plaque (1783 and 1874 flood marks), as Fig. 5 shows.

When no limnimark was found, the maximum water height was estimated from information found in contemporary accounts; more precisely:
1. 1615 flood: an indication of maximum water height was found in Llibre d'Actes i Memòries: 1603-1621 (ACUR, 1621; Farré, 2008). It says that the flood reached the ball playground located in Font Street (approximately $366.0 \mathrm{~m}$ a.s.1.).

2. 1842 flood: according to the account written by Salvadó (1875), the water arrived somewhat further than the main door of the Codina mill, the remains of which are still to be found at Sant Agustí Street. We estimated this maximum water height as $363.5 \mathrm{~m}$ a.s.l., i.e., the height of the door threshold.

3. 1930 and 1989 floods: several journalistic accounts are conserved from these floods. Crònica Targarina (Anonymous, 1930) and La Vanguardia (Castellà and Miranda, 1989) describe how the water overflowed at the end of the Carlist Wall and how it flowed back up to the beginning of Sant Agustí Street. We estimated these heights as 363.4 and $363.3 \mathrm{~m}$ a.s.l., respectively.

Since an actual line is usually more precisely placed (and, thus, measured) than a description of that line, the accuracy of the water height estimation is higher when done from a limnimark than from a written account: $5 \mathrm{~mm}$ against $5 \mathrm{~cm}$ (Table 1); this gives an idea of the importance of limnimarks in historical flood reconstruction. 


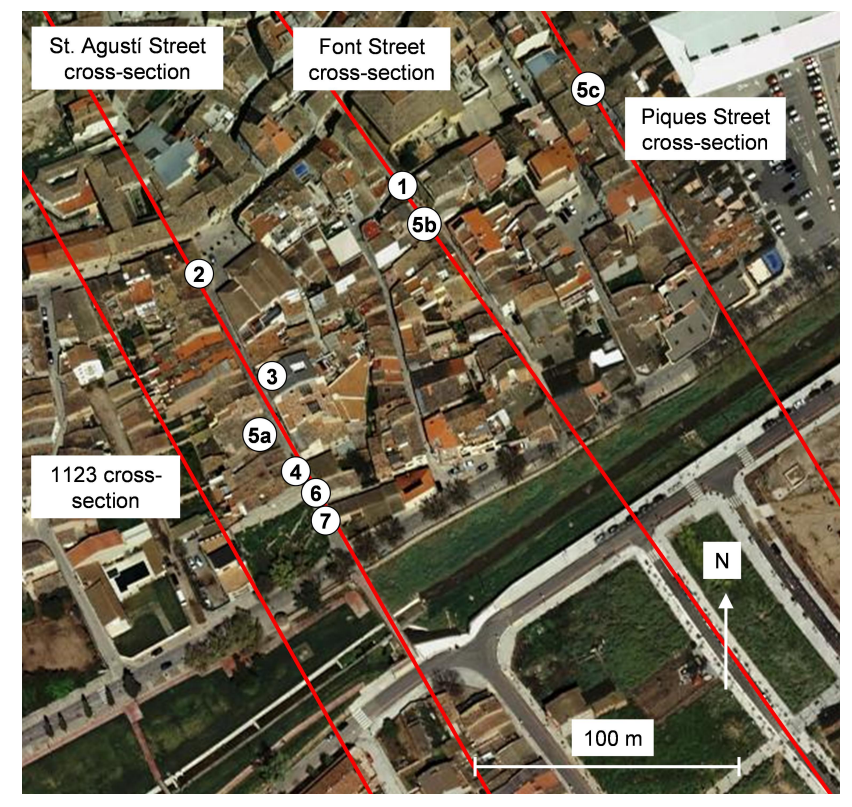

Fig. 6. Location of the nine observed maximum water heights of the seven studied floods, obtained from historical information (a key can be found in Table 1); and the four reference cross-sections used when comparing observed and modelled water heights.

In total, we found nine documented maximum water height observations, one for each of the seven floods, except for the 1874 flood, which had three (Fig. 6). In that specific case, one observation was used to model the flood and the remaining two, to visually assess the accuracy of the modelled flow.

Each historically observed maximum water height was compared to the modelled height at a particular cross-section, called the reference cross-section, which usually was the closest one to the observation. Actually, four different crosssections had to be used to properly compare the nine observed water heights to the nine modelled ones:

1. Piques Street cross section, $1333 \mathrm{~m}$ upstream of the junction with the Cercavins River, for one of the observations of 1874 flood (observation 5c in Fig. 6).

2. Font Street cross-section, $1245 \mathrm{~m}$ upstream of the junction with the Cercavins River, for the 1615 flood observation (observation 1 in Fig. 6) and for one of 1874 flood (observation 5b in Fig. 6).

3. Sant Agustí Street cross-section, $1147 \mathrm{~m}$ upstream of the junction with the Cercavins River, for 1644, 1783, 1842 and 1874 floods' maximum water height observations (observations 2, 3, 4 and 5a in Fig. 6).

4. A cross-section $1123 \mathrm{~m}$ upstream of the junction with the Cercavins River, for 1930 and 1989 floods' maximum water height observations (observations 6 and 7

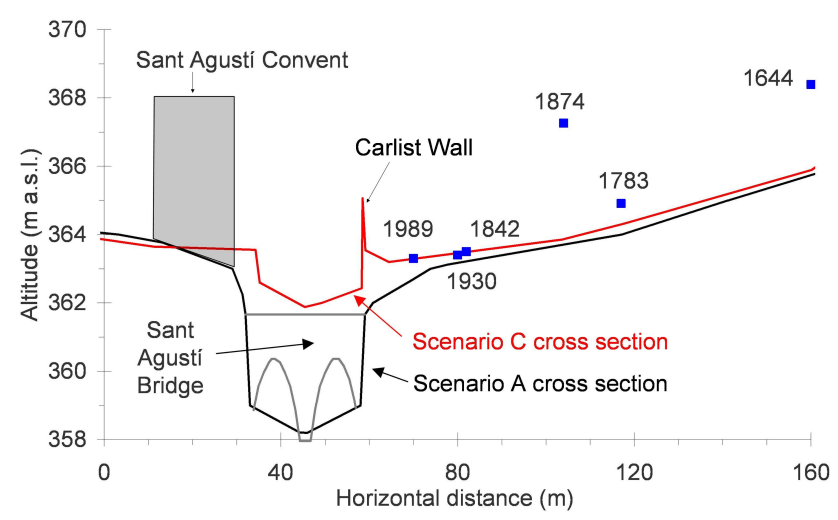

Fig. 7. Sant Agustí Street cross-section in scenarios A and C as seen from upstream with the six water height historical observations found in Sant Agustí Street. Scenario A includes Sant AgustíBridge and Convent and Scenario C, the Carlist Wall, which is higher than 1930 and 1989 floods maximum heights, as explained in Sect. 3.1. (Horizontal axis marks the distance from an arbitrary spot on the left bank).

in Fig. 6). In these cases, the observed maximum water heights do not mark the height of the streamflow at the cross-section where they were placed (Sant AgustíStreet's) but at the spot where the two floods overflowed the right bank and flowed back along the town-side of the Carlist Wall; as explained above, this overflowing spot was the downstream end of the Carlist Wall, i.e. 1123 cross-section. Actually, both observed water heights were lower than the Carlist Wall at Sant Agustí Street cross-section (Fig. 7) and, thus, the right bank was not hydraulically connected with the channel in that spot.

\subsection{Channel's and floodplain's morphology}

Present-day channel's and floodplain's morphology was defined with 53 cross-sections obtained from a 1:1000 map; moreover, Sant Agustí Street section was measured with topographic equipment in order to increase its precision, since it was the reference section in four of the flood reconstructions. Transition between two contiguous cross-sections was defined by expansion and contraction coefficients, which were chosen among the HEC-RAS tabulated values.

Afterwards, combinations of the corresponding changes explained in Sect. 2.2 were added to present-day morphology and we obtained three different morphologies or scenarios, which were used in modelling the corresponding floods.

1. Scenario A (pre-1874 scenario): the river bed was three metres below present-day one, and its longitudinal slope was $0.95 \%$ just upstream of Sant Agustí Street crosssection and $0.24 \%$ just downstream of it. Sant Agustí Bridge was not buried, the Mediaeval Wall ran along 
the right bank and Sant Agustí Convent lay on the left floodplain. 1615, 1644, 1783, 1842 and 1874 floods were modelled on this scenario.

2. Scenario B (1874 scenario): the river bed was the present-day one, with a longitudinal slope of $0.15 \%$ just upstream of Sant Agustí Street cross-section and 1\% just downstream of it. Sant Agustí Bridge and the Mediaeval Wall were completely buried and Sant Agustí Convent lay on the left floodplain. 1874 flood was modelled on this scenario, as well as on scenario A.

3. Scenario C (post-1874 scenario): the river bed was the present-day one, as in scenario B. Sant Agustí Bridge and the Mediaeval Wall were completely buried, the Carlist Wall ran along the right bank, Sant Agustí Convent was replaced by Sant Agustí Slum on the left floodplain, and two new bridges were in place: C-14 road's and LV-2021 road's. 1930 and 1989 floods were modelled on this scenario.

\subsection{Channel's and floodplain's roughness}

Channel's and floodplain's roughness, which accounts for friction against the flow, is quantified, for the use in HECRAS software, with Manning's $n$, which is estimated from tables that give its value on different river types and land uses (Chow, 1959).

Aerial photos and historical maps and documents were used to determine the different land uses around the studied reach of the river at the time of each flood. Obviously, the uncertainty of such a determination increases for older floods. However, we hypothesized (and we found no evidence of the contrary) that no great changes occurred between the 17th and 19th centuries.

Actually, each cross-section was divided into homogeneous land-use segments, which were assigned a Manning's $n$ value from tabulated values, as in the example shown in Table 2. Then a composed value for the cross-section was calculated weight-averaging the land-use segments' values. This value varied according to the modelling scenario: for instance, Sant Agustí Street cross-section had a composed Manning's $n$ of 0.089 in scenario A and 0.070 in both scenario $\mathrm{B}$ and $\mathrm{C}$.

\subsection{Uncertainty assessment}

The input data required in historical flood reconstruction are old-time magnitudes. Unfortunately, estimating old-time magnitudes from historical information can never be as accurate as measuring present-day ones on a field survey.

In order to assess the influence of the limited accuracy of some input data on the peak flow results, several sensitivity analyses were done at Sant Agustí Street cross-section:

1. The first sensitivity analysis was performed on a high peak flow $\left(1200 \mathrm{~m}^{3} \mathrm{~s}^{-1}\right)$ in scenario $\mathrm{A}$; it quantified the
Table 2. Land uses identified at Sant Agustí Street cross-section (number 1147) in scenario C and their related Manning's $n$ values.

\begin{tabular}{llc}
\hline $\begin{array}{l}\text { Cross-section } \\
\text { segment }\end{array}$ & $\begin{array}{l}\text { Land } \\
\text { use }\end{array}$ & $\begin{array}{c}\text { Manning's } \\
n\end{array}$ \\
\hline \multirow{2}{*}{ Channel } & Non-vegetated channel & 0.035 \\
& Vegetated channel & 0.075 \\
\hline \multirow{3}{*}{ Bank } & Road & 0.037 \\
& Field & 0.040 \\
& Meadow & 0.065 \\
& Urban area & 0.100 \\
& Riparian forest & 0.116 \\
\hline
\end{tabular}

influence of an error in the observed maximum water height on the peak flow value .

2. The second sensitivity analysis was also performed on a high peak flow $\left(1200 \mathrm{~m}^{3} \mathrm{~s}^{-1}\right)$ in scenario A; it quantified the influence of an error in Manning's $n$ on the peak flow value .

3. The third sensitivity analysis was performed on a low peak flow $\left(300 \mathrm{~m}^{3} \mathrm{~s}^{-1}\right)$ in scenario $\mathrm{C}$; it quantified the influence of an error in Manning's $n$ on the peak flow value.

Afterwards, the results of the sensitivity analyses were quadratically summed to obtain the peak flows' uncertainty, hypothesizing that water height uncertainty was $5 \mathrm{~cm}$ (for values found in written accounts) or $0.5 \mathrm{~cm}$ (for values found in limnimarks) and that Manning's $n$ uncertainty was $25 \%$, estimated from the average range within a tabulated category (Chow, 1959).

This uncertainty assessment could be improved by including a sensitivity analysis on morphology measurement errors, which is a major factor in hydraulic modelling (especially, longitudinal slope). Besides, an even more thorough uncertainty assessment could include other factors, such as backwater effects and lateral flows (not taken into account in a one-dimensional modelling software), non-permanent flow effects (not taken into account in a steady flow procedure) or the undulations of the water surface.

\section{Results and discussion}

\subsection{Hydraulic modelling}

As results in Table 3 and Fig. 8 show, the morphology scenario strongly determined the hydraulic behaviour of the modelled flows:

1. First, in scenario A, the flows of four different floods' behave similarly along the modelled river reach regardless of their peak flow magnitude: water longitudinal 

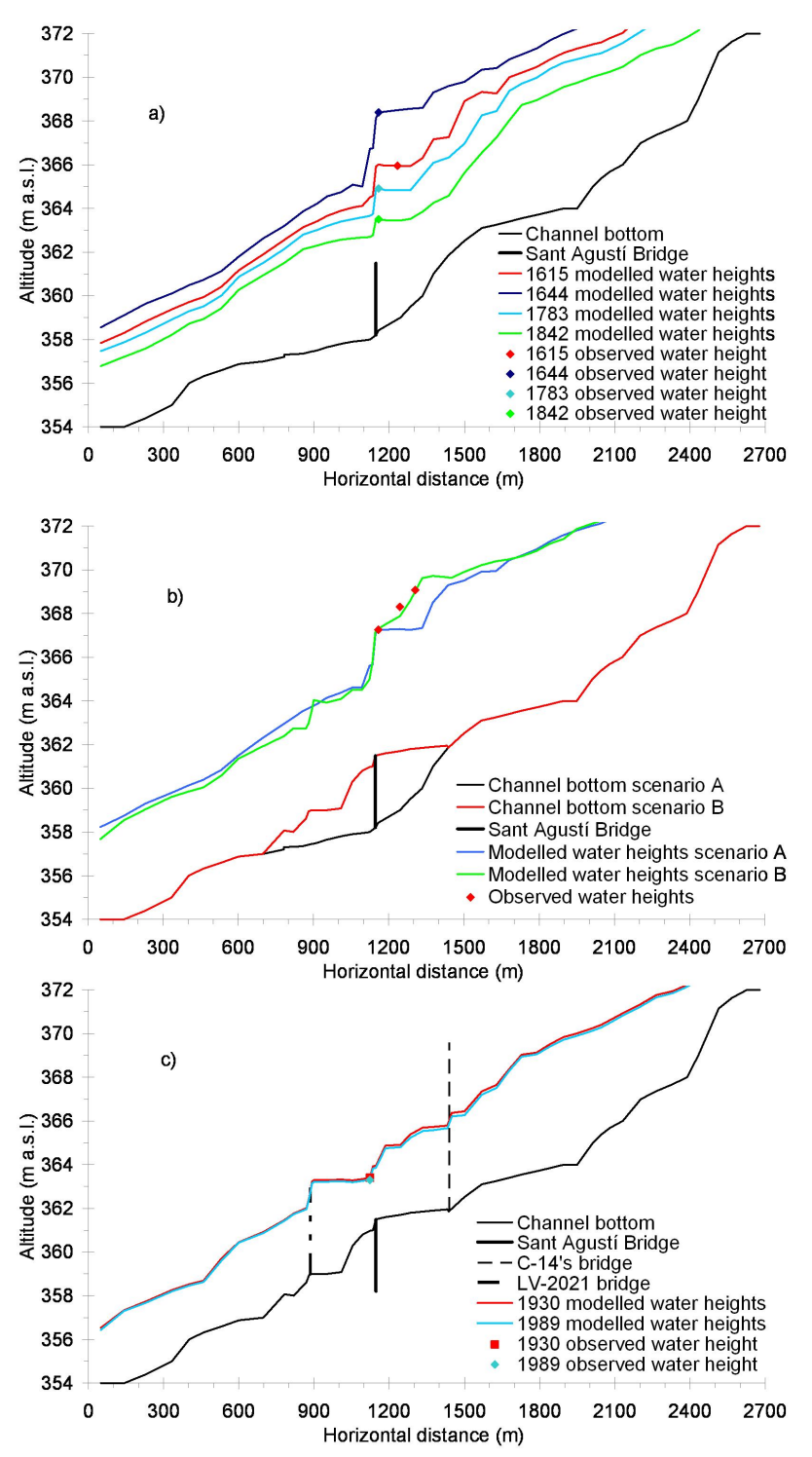

Fig. 8. Modelled and observed maximum water heights of the seven floods: 1615, 1644, 1783 and 1842 floods modelled in scenario A (a); 1874 flood modelled in both scenario A and B, the latter fitting better the three observations recorded in each of the three limnimarks (b); and 1930 and 1989 floods modelled in scenario $\mathrm{C}(\mathbf{c})$. (Horizontal axis marks the distance from the junction with the Cercavins River).

profiles are parallel (Fig. 8a); indeed, they are horizontal, just upstream of Sant Agustí Bridge for about $180 \mathrm{~m}$ and they all fall abruptly downstream of that bridge. The reason for this is that Sant Agustí Bridge acts as a dam (because the bridge's spans cannot convey all the flow) and, thus, the water builds up behind it and eventually jumps over it, like over a weir; in other words, the bridge causes a raise of the water level above the one that could have been observed had not the bridge been in place. Actually, Agustí Bridge caused a raise of the water surface of $1 \mathrm{~m}$ for the 1842 flood's peak $\left(210 \mathrm{~m}^{3} \mathrm{~s}^{-1}\right)$ and of $3.4 \mathrm{~m}$ for the 1644 flood's peak $\left(1600 \mathrm{~m}^{3} \mathrm{~s}^{-1}\right)$, as can be seen in Fig. 8a. This explains the concentration of historical flood information at Sant Agustí Street: the over-risen flow easily flooded that area, causing much damage and, therefore, a great impact of the floods, which were recorded on limnimarks and written accounts.

2. On the other hand, in scenario B, which only differed from $\mathrm{A}$ in the 3-m-deep sediment layer, the water's longitudinal profile of the 1874 flood displays an horizontal segment between $180 \mathrm{~m}$ and $300 \mathrm{~m}$ upstream of Sant Agustí Bridge and then a steep slope between the end of that segment and the bridge, which becomes steeper after the bridge (Fig. 8b). The deposition of the 3-m-deep sediment layer explains this behaviour, since it covered the bridge, thus reducing six times the channel's longitudinal slope just upstream of that structure and increasing it four times just downstream of it. Thus, the hydraulic configuration was no longer that of a dam, but that of a succession of a slow segment, a faster one and a waterfall. In any case, 1874 modelled peak flow value was the same in either scenario A and B.

3. Finally, in scenario C, in spite of including the same 3$\mathrm{m}$-deep sediment layer, the flow behaviour of the 1930 and 1989 floods is different from 1874's for two reasons: the modest magnitude of these floods' peak flows compared to that of 1874 and the presence downstream of the LV-2021 road's bridge, which created a dam effect that reached past Sant Agustí Street cross-section (Fig. 8c).

The comparison of peak flows and water heights at Sant Agustí Street cross-section between 1842, 1930 and 1989 floods, and between those of the 1874 flood in scenarios A and $B$ points out that, in spite of the section area reduction caused by the deposition of the 3-m-deep sediment layer and the construction of the Cartlist Wall, Sant Agustí Street crosssection is hydraulically more efficient in scenarios B and C than in $\mathrm{A}$; that is, the same peak flow is conveyed with a smaller water height. This effect is more evident in lower peak flows (1842, 1930 and 1989 floods) and results in less flooding due to modest events.

This hydraulic efficiency increase is due to the acceleration of the flow caused by, on the one hand, Manning's $n$ reduction and, on the other hand, the absence of the Sant Agustí Bridge, buried by the 1874 flood sediment layer, which acted as a dam in the occurrence of a heavy flood. Indeed,in the new hydraulic conditions, the flow is much faster - its velocity more than doubles - and, thus, has a higher destruction capacity.

That sediment layer was deposited during the 1874 flood; not knowing if that happened before or after the peak flow, 

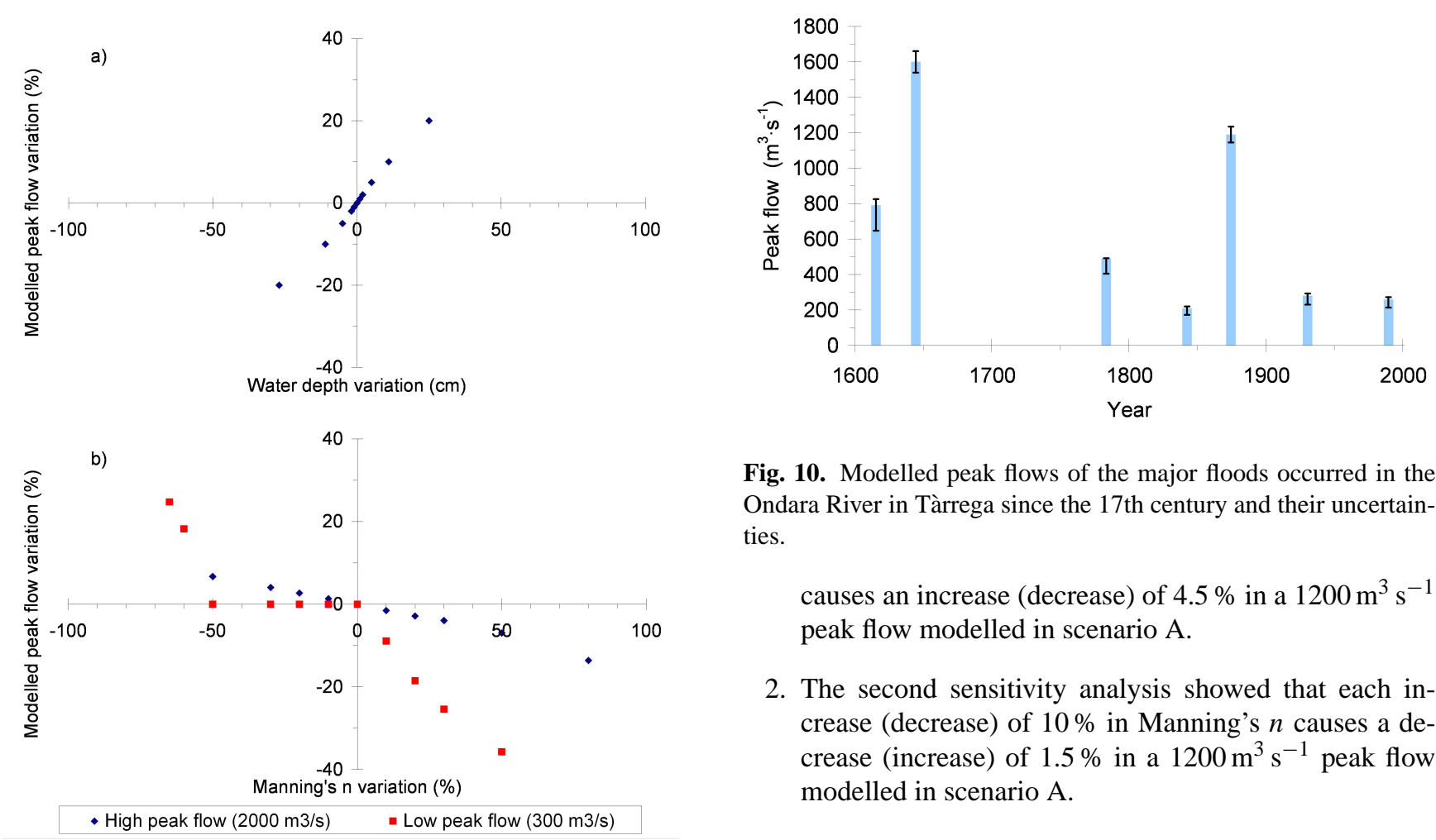

Fig. 10. Modelled peak flows of the major floods occurred in the Ondara River in Tàrrega since the 17 th century and their uncertainties.

causes an increase (decrease) of $4.5 \%$ in a $1200 \mathrm{~m}^{3} \mathrm{~s}^{-1}$ peak flow modelled in scenario A.

2. The second sensitivity analysis showed that each increase (decrease) of $10 \%$ in Manning's $n$ causes a decrease (increase) of $1.5 \%$ in a $1200 \mathrm{~m}^{3} \mathrm{~s}^{-1}$ peak flow modelled in scenario A.

Fig. 9. Results of the sensitivity analyses performed by varying historically observed maximum water height (a) and Manning's $n$ (b).

that flood was modelled in both scenarios A and B. The lucky existence of two additional limnimarks allowed us to decide that scenario B results fitted better with the actual flood (Fig. 8b) and, therefore, that the sediment was mainly deposited before the peak flow, that is, during the ascending limb of the hydrograph.

Since the 1644 flood's peak flow was even higher than 1874 's, a similar sediment deposition might as well have occurred at that time. However, the 1668 Pier Maria Baldi's drawing does not show such an accretion and there is no proof of dredging between the flood's and the drawing's dates. Therefore, the 1874 flood's sediment deposition might be related to factors other than the mere peak flow value, such as the hydrograph shape, the flood's duration or even possible changes in land uses within the catchment.

\subsection{Uncertainty assessment of the hydraulic modelling}

The results of the sensitivity analyses displayed in Table 4 and Fig. 9 show that the relationships between the variation of the modified input magnitudes and the variation of the modelled peak flow are linear within the explored range of input magnitude:

1. The first sensitivity analysis showed that each increase (decrease) of $5 \mathrm{~cm}$ in historically observed water height

3. The third analysis showed that an increase of $10 \%$ in Manning's $n$ causes a decrease of $7 \%$ in a $300 \mathrm{~m}^{3} \mathrm{~s}^{-1}$ peak flow modelled in scenario $\mathrm{C}$; whereas a decrease of up to $50 \%$ causes no variation, and a decrease of a further $10 \%$ causes an increase of $17 \%$ in the peak flow. The reason of the strange shape of this relationship is that this peak flow is coincidentally the critical flow and, in such a case, the hydraulic modelling software finds the same resulting flow even if the input data are modified within a range around their critical values.

According to these results and to the fact that it is far more difficult to estimate the channel's roughness than to measure a water height, Manning's $n$ had a much greater influence in peak flow uncertainty than historically observed water height, and that influence was even greater in low flows.

As a first approach to quantifying the results accuracy, we applied the results of the first and the second analyses to high flows (1644 and 1874 floods) and those of the first and the third ones to low flows (the rest of the floods) and then quadratically summed the resulting relative uncertainties, and obtained that peak flow uncertainty was $\pm 4 \%$ for high peak flows and $(-18 \%,+4.5 \%)$ for low peak flows, except for the 1783 flood, which was $(-18 \%,+0.45 \%)$ (Table 5 and Fig. 10). The assimetry of the uncertainty intervals for low peak flows is caused by the strange shape of the third sensitivity analysis explained above. This uncertainty is very low when compared to the $50 \%$ estimated by Gaume et al. (2004) in flood reconstruction in the Aude River (France).

Indeed, our results' uncertainty is underestimated because its assessment did not include the possible influence of 
Table 3. Results of the hydraulic modelling at the time of the peak flow.

\begin{tabular}{|c|c|c|c|c|c|c|c|c|c|}
\hline Flood & Scenario & $\begin{array}{l}\text { Reference } \\
\text { cross } \\
\text { section* }\end{array}$ & $\begin{array}{r}\text { Channel's bottom } \\
\text { height at reference } \\
\text { cross-section ( } \mathrm{m} \text { a.s.1.) }\end{array}$ & $\begin{array}{c}\text { Peak flow } \\
\left(\mathrm{m}^{3} \mathrm{~s}^{-1}\right)\end{array}$ & $\begin{array}{r}\text { Specific peak } \\
\text { flow } \\
\left(\mathrm{m}^{3} \mathrm{~s}^{-1} \mathrm{~km}^{-2}\right)\end{array}$ & $\begin{array}{r}\text { Water height at } \\
1147 \text { cross } \\
\text { section }(\mathrm{m})\end{array}$ & $\begin{array}{r}\text { Wetted area at } \\
1147 \text { cross } \\
\text { section }\left(\mathrm{m}^{2}\right)\end{array}$ & $\begin{array}{r}\text { Mean water velocity } \\
\text { at } 1147 \text { cross } \\
\text { section }\left(\mathrm{m} \mathrm{s}^{-1}\right)\end{array}$ & $\begin{array}{r}\text { Froude's number at } \\
1147 \text { cross } \\
\text { section }\end{array}$ \\
\hline 1615 & \multirow{4}{*}{ A } & 1245 & 359.0 & 790 & 5.3 & 7.3 & 293 & 2.7 & 0.38 \\
\hline 1644 & & 1147 & 358.2 & 1600 & 10.7 & 10.19 & 516 & 3.1 & 0.39 \\
\hline 1783 & & 1147 & 358.2 & 490 & 3.3 & 6.71 & 233 & 2.1 & 0.38 \\
\hline 1842 & & 1147 & 358.2 & 210 & 1.4 & 5.3 & 124 & 1.7 & 0.36 \\
\hline \multirow{2}{*}{1874} & A & \multirow{2}{*}{1147} & 358.2 & 1190 & 7.9 & 9.06 & 425 & 2.8 & 0.39 \\
\hline & B & & 361.5 & 1190 & 7.9 & 5.76 & 277 & 4.3 & 0.63 \\
\hline 1930 & \multirow[b]{2}{*}{$\mathrm{C}$} & 1123 & 361.0 & 280 & 1.9 & 2.5 & 67 & 4.2 & 1.00 \\
\hline 1989 & & 1123 & 361.0 & 260 & 1.7 & 2.4 & 63 & 4.1 & 1.00 \\
\hline
\end{tabular}

* The reference cross-section is the closest one to the historical water height observation and its number is the distance (in metres) from the cross-section to the downstream extreme of the reach: the junction of the Ondara with the Cercavins River.

Table 4. Results of the sensitivity analyses performed by varying historically observed maximum water height and Manning's $n$.

\begin{tabular}{|c|c|c|c|c|c|c|c|c|c|}
\hline \multirow[b]{2}{*}{$\begin{array}{l}\text { Sensitivity } \\
\text { analysis }\end{array}$} & \multirow[b]{2}{*}{ Scenario } & \multirow[b]{2}{*}{$\begin{array}{l}\text { Peak flow } \\
\left(\mathrm{m}^{3} \mathrm{~s}^{-1}\right)\end{array}$} & \multirow[b]{2}{*}{$\begin{array}{l}\text { Modified input } \\
\text { magnitude }\end{array}$} & \multicolumn{3}{|c|}{$\begin{array}{c}\text { Peak flow variation } \\
\text { due to a variation of } 5 \mathrm{~cm} \text { in } \\
\text { historically observed water height }\end{array}$} & \multicolumn{3}{|c|}{$\begin{array}{l}\text { Peak flow variation } \\
\text { due to a variation of } \\
10 \% \text { in Manning's } n\end{array}$} \\
\hline & & & & $\begin{array}{r}\text { Results validity } \\
\text { range }^{\mathrm{a}} \\
(\mathrm{cm})\end{array}$ & $\begin{array}{r}\text { Peak flow } \\
\text { variation } \\
(\%)\end{array}$ & $\begin{array}{l}\text { Peak flow } \\
\text { variation } \\
\left(\mathrm{m}^{3} \mathrm{~s}^{-1}\right)\end{array}$ & $\begin{array}{r}\text { Results validity } \\
\text { range }^{b} \\
(\%)\end{array}$ & $\begin{array}{r}\text { Peak flow } \\
\text { variation } \\
(\%)\end{array}$ & $\begin{array}{r}\text { Peak flow } \\
\text { variation } \\
\left(\mathrm{m}^{3} \mathrm{~s}^{-1}\right)\end{array}$ \\
\hline 1 & A & 1200 & Water height & -50 to 100 & 4.5 & 54 & - & - & - \\
\hline 2 & A & 1200 & Manning's $n$ & - & - & - & -50 to 80 & -1.5 & -18 \\
\hline 3 & $\mathrm{C}$ & 300 & Manning's $n$ & - & - & - & $\begin{array}{r}-65 \text { to }-50 \\
-50 \text { to } 0 \\
0 \text { to } 80\end{array}$ & $\begin{array}{r}-17 \\
0 \\
-7\end{array}$ & $\begin{array}{r}-5.1 \\
0 \\
-2.1\end{array}$ \\
\hline
\end{tabular}

${ }^{a}$ Range of historically observed water height in which the relationship between variation of historically observed water height and variation of modelled peak flow is linear.

b Range of Manning's $n$ in which the relationship between variation of Manning's $n$ and variation of modelled peak flow is linear.

morphological factors' uncertainties (i.e. longitudinal slope) and of the use of certain hydraulic modelling options (a onedimensional, steady flow) instead of more realistic ones (a two-dimensional, unsteady flow). For example, the reconstructed peak flow of the 1874 flood in the neighbouring Sió River's catchment decreases $8 \%$ if modelled as an unsteady instead of a steady flow, probably due to the former taking into account floodplain storage (Tuset, 2011).

\subsection{Hydrological analysis of the peak flows}

Four out of the seven studied floods (1615, 1783, 1842 and 1874) are listed in some compilations of historical floods in the Iberian Peninsula (Barriendos and Rodrigo, 2006; Barnolas and Llasat, 2007), which classify them as Large Catastrophic Events (LCE), that is, floods that simultaneously affected two or more large basins.

Oddly enough, and despite its magnitude, the 1644 flood is not collated in these compilations and neither is there a record of it in neighbouring catchments. Therefore, this event was most probably caused by a very local storm over an area of less than $200 \mathrm{~km}^{2}$.
It was indeed a heavy flood, because its modelled specific flow $\left(10.7 \mathrm{~m}^{3} \mathrm{~s}^{-1} \mathrm{~km}^{-2}\right)$, along with that of the 1874 flood $\left(7.9 \mathrm{~m}^{3} \mathrm{~s}^{-1} \mathrm{~km}^{-2}\right)$, were much higher than the highest ever measured in similar-sized catchments within the Ebro River basin: $5.4 \mathrm{~m}^{3} \mathrm{~s}^{-1} \mathrm{~km}^{-2}$ in the Seco River at Oliete in 1945 and $3.3 \mathrm{~m}^{3} \mathrm{~s}^{-1} \mathrm{~km}^{-2}$ in the Algars River at Horta de Sant Joan in 1967 (López-Bustos, 1981).

However, an overestimation of the modelled peak flows should be ruled out because these specific flows are congruent with the highest modelled in similar-sized Catalan catchments, which have an enveloping curve value of $10 \mathrm{~m}^{3} \mathrm{~s}^{-1} \mathrm{~km}^{-2}$ (Gaume et al., 2009). Similarly, Delrieu et al. (2005) and Payrastre et al. (2005) have modelled specific flows of this order in neighbouring Southern France.

\subsection{Temporal trends}

The reconstructed peak flows are shown on a time scale in Fig. 10. The floods temporal distribution is quite regular; the periods between them are of 30-60 yr, except between 1644 and 1783 (139 yr). 
Table 5. Peak flow error intervals due to historically observed water height and Manning's $n$. (Precision of the historically observed water height was $0.5 \mathrm{~cm}$ when obtained from limnimarks (1640, 1783 and 1874 floods) and $5 \mathrm{~cm}$ when obtained from other historical sources (1615, 1842, 1930 and 1989) and Manning's $n$ precision was estimated as $25 \%$ in all cases; accordingly to the sensitivity analyses, the relative error of the peak flow due to a $5 \mathrm{~cm}$ error in historically observed water height was $4.5 \%$, and that due to a $10 \%$ increase in Manning's $n$ was $-1.5 \%$ for high peak flows and $-7 \%$ for low peak flows and $1.5 \%$ and $0 \%$, respectively, for a $10 \%$ decrease in Manning's $n ; 1000 \mathrm{~m}^{3} \mathrm{~s}^{-1}$ was the limit chosen between high and low peak flows).

\begin{tabular}{rrrrrrr}
\hline \multirow{2}{*}{ Flood } & \multirow{2}{*}{$\begin{array}{c}\text { Peak flow } \\
\left(\mathrm{m}^{3} \mathrm{~s}^{-1}\right)\end{array}$} & \multicolumn{2}{c}{$\begin{array}{c}\text { Peak flow relative } \\
\text { error interval extremes }(\%)\end{array}$} & & $\begin{array}{c}\text { Peak flow absolute error } \\
\text { interval extremes }\left(\mathrm{m}^{3} \mathrm{~s}^{-1}\right)\end{array}$ \\
& & Negative & Positive & & Negative & Positive \\
\hline 1615 & 790 & -18 & 4.5 & & -140 & 40 \\
1644 & 1600 & -4 & 4 & & -60 & 60 \\
1783 & 490 & -18 & 0.45 & & -90 & 2 \\
1842 & 210 & -18 & 4.5 & & -40 & 10 \\
1874 & 1190 & -4 & 4 & & -50 & 50 \\
1930 & 280 & -18 & 4.5 & & -50 & 10 \\
1989 & 260 & -18 & 4.5 & -50 & 10 \\
\hline
\end{tabular}

All the studied floods that took place within the Little Ice Age (LIA) - that is, between the 15th and 19th centuries (Pfister et al., 1996) -, except that of 1644, occurred in periods in which catastrophic flash floods were more frequent in Catalonia: 1580-1620, 1760-1800 and 1830-1870 (Barriendos and Martin-Vide, 1998; Llasat et al., 2005).

However, this higher frequency does not seem to be related to climate evolution since there are differences between those periods: the first and the last of them were especially cold and wet, whereas the second one, known as Maldà's anomaly, was very dry (Barriendos and Llasat, 2003). Furthermore, during the coldest period within the LIA in Central and Northern Europe, the Late Maunder Minimum (16751715), no floods were recorded in the Ondara's catchment. Therefore, the extreme weather that caused the five pre-1900 flash-floods does not seem to be related to a period's wetness or coldness.

Nevertheless, pre- and post-1900 floods might have had different climatic causes. Indeed, the five pre-1900 floods occurred between late July and late September and all of them except again the 1644 flood, which was exceptional in more than one way - did not last long, a sign of their convective origin. Conversely, post-1900 floods both took place in the second half of October and were caused by weather fronts.

\section{Conclusions}

There is no flow gauging data of the Ondara River; nevertheless, the great availability of historical information about floods and urban evolution of the town of Tàrrega allowed the hydraulic reconstruction of the major floods occurred since the 17 th century.

This reconstructed information will probably improve flood prediction in Tàrega, because of the magnitude of the modelled floods: two of the calculated specific peak flows are among the highest ever modelled in similar-sized catchments in the Western Mediterranean basin.

Besides, archaeological surveys uncovered a great modification in the channel's and floodplain's morphology operated by 1874 flood: a 3-m-deep sediment layer deposition. Afterwards, our reconstruction proved that this deposition occurred before the peak flow and, thus, had an influence on the flood's characteristics: it accelerated the flow and, therefore, it increased its destruction capacity. At the same time, this morphology change caused the modest flows to be less prone to flooding than previously.

The sensitivity analyses showed that Manning's $n$ had more influence in the modelled peak flows values than water height. Furthermore, a preliminary uncertainty assessment taking only into account observed water height and Manning's $n$ estimated the peak flows' error in $4 \%$ for high flows and $18 \%$ for low flows.

Acknowledgements. We thank the anonymous people who decided to keep records of ancient floods, either in the form of limnimarks or written accounts, which allowed the reconstruction of these events. We also thank Ruben Remacha (University of Lleida) and Francesc Marsà (Catalonia Water Agency), who told us about Tàrrega's limnimarks; Oriol Saula (Urgell County Museum), who told us a lot about Ondara's floodplain's morphology evolution; and Miquel Àngel Farré (Urgell County Archive), who helped us to find some documents. We also thank the two anonymous referees who reviewed the text and the editor of the volume Aristides Bartzokas for their work in improving the article. One of the authors belongs to the RIUS Fluvial Dynamics Research Group (UdL) and was funded by the Catalonia Water Agency (ACA) (CV08000251).

Edited by: A. Bartzokas

Reviewed by: two anonymous referees 


\section{References}

Balasch, J. C., Ruiz-Bellet, J. L., Tuset, J., and Martín de Oliva, J.: Reconstruction of the 1874 Santa Tecla's rainstorm in Western Catalonia (NE Spain) from flood marks and historical accounts, Nat. Hazards Earth Syst. Sci., 10, 2317-2325, doi:10.5194/nhess-10-2317-2010, 2010a.

Balasch, J. C., Tuset, J., and Ruiz-Bellet, J. L.: Reconstructing the 1874 Santa Tecla flash flood in the Ondara River (Ebro Basin, NE Spain), Adv. Geosci., 26, 45-48, doi:10.5194/adgeo-26-452010, 2010b.

Barnolas, M. and Llasat, M. C.: Metodología para el estudio de inundaciones históricas en España e implementación de un SIG en las cuencas del Ter, Segre y Llobregat. CEH-CEDEX, Monografías M-90, Ministerio de Fomento, Madrid, 264 pp., 2007.

Barriendos, M. and Llasat, M. C.: The case of the "Maldà" anomaly in the Western Mediterranean basin (AD 1760-1800): an example of a strong climatic variability, Climatic Change, 61, 191216, 2003

Barriendos, M. and Martín-Vide, J.: Secular climatic oscillations as indicated by catastrophic floods in the Spanish Mediterranean coastal area (14th-19th centuries), Climatic Change, 38, 473491, 1998.

Barriendos, M. and Rodrigo, F. S.: Study of historical flood events on Spanish rivers using documentary data, Hydrol. Sci. J., 51, 765-783, 2006.

Bayliss, A. C. and Reed, D. W.: The use of historical data in flood frequency estimation, CEH-NERC, Wallingford, UK, 2001.

Benito, G., Díez-Herrero, A. M., and Fernández de Villalta, M.: Magnitude and frequency of flooding in the Tagus basin (central Spain) over the last millennium, Climate Change, 58, 171-192, 2003.

Benito, G., Thorndycraft, V. R., Rico, M., Sánchez-Moya, Y., and Sopeña, A.: Paleoflood and floodplain records from Spain: Evidence for long-term climate variability and environmental changes, Geomorphology, 101, 68-77, 2008.

Chow, V. T.: Open-channel hydraulics, McGraw-Hill, New York, 680 pp., 1959.

Confederación Hidrográfica del Ebro (CHE): Propuesta de Plan Hidrológico de la Cuenca del Ebro, Anexo 2: Aportaciones de las estaciones de aforo. Ministerio de Medio Ambiente, Medio Rural y Marino, Madrid, 1996.

Delrieu, G., Ducrocq, V., Gaume, E., Nicol, J., Payrastre, O., Yates, E., Kirstetter, P. E., Andrieu, H., Ayral, P. A., Bouvier, C., Creutin, J. D., Livet, M., Anquetin, S., Lang, M., Neppel, L., Obled, C., Parent-du-Châtelet, J., Saulnier, G. M., Walpersdorf, A., and Wobrock, W.: The Catastrophic Flash-Flood Event of 8-9 Septembre 2002 in the Gard Region, France: A First Case Study of the Cévennes-Vivarais Mediterranean Hydrometeorological Observatory, J. Hydrometeorol., 6, 34-52, 2005.

Gaume, E., Livet, M., Desbordes, M., and Villeneuve, J.: Hydrological analysis of the river Aude, France, flash flood on 12 and 13 November 1999. J. Hydrol., 286, 135-154, 2004.

Gaume, E., Bain, V., Bernardara, P., Newinger, O., Barbuc, M., Bateman, A., Blaskovicova, L., Blöschi, G., Borga, M., Dumitrescu, A., Daliakopoulos, I., Garcia, J., Irimescu, A., Kohnova, S., Koutroulis, A., Marchi, L., Matreata, S., Medina, V., Preciso, E., Sempere-Torres, D., Stancalie, G., Szolgay, J., Tsanis, I., Velasco, D., and Viglione, A.: A compilation of data on European flash floods, J. Hydrol., 367, 70-78, 2009.
Lang, M., Fernández-Bono, J. F., Recking, A., Naulet, R., and Grau-Gimeno, P.: Methodological guide for paleoflood and historical peak discharge estimation, in: Systematic Paleoflood and Historical Data for the Improvement of Flood Risk Estimation, edited by: Bernito, G. and Thorndycraft, V. R., Methodological Guidelines, Centro de Ciencias Medioambientales, Madrid, 4353, 2004.

Llasat, M. C., Rigo, T., and Barriendos, M.: The "Montserrat-2000" flash-flood event: a comparison with the floods that have occurred in the northeastern Iberian Peninsula since the 14th century, Int. J. Climatol., 23, 453-469, 2003.

Llasat, M. C., Barriendos, M., Barrera, T., and Rigo, T.: Floods in Catalonia (NE Spain) since the 14th Century, Climatological and meteorological aspects from historical documentary sources and old instrumental records, J. Hydrol., 313, 32-47, 2005.

López-Bustos, A.: Tomando el pulso a las grandes crecidas de los ríos peninsulares, Revista de Obras Públicas, 3190, 179-192, 1981.

Naulet, R., Lang, M., Ouarda, T. B. M. J., Coeur, D., Bobée, B., Recking, A., and Moussay, D.: Flood frequency analysis on the Ardèche river using French documentary sources from the last two centuries, J. Hydrol., 313, 58-78, 2005.

Ortega, J. A. and Garzón, G.: A contribution to improved flood magnitude estimation in base of palaeoflood record and climatic implications - Guadiana River (Iberian Peninsula), Nat. Hazards Earth Syst. Sci., 9, 229-239, doi:10.5194/nhess-9-2292009, 2009.

Payrastre, O., Gaume, E., and Andrieu, H.: Use of historical data to assess the occurrence of floods in small watersheds in the French Mediterranean area, Adv. Geosci., 2, 313-320, doi:10.5194/adgeo-2-313-2005, 2005.

Pfister, C., Swartz-Zanetti, G., and Wegmann, M.: Winter severity in Europe: The Fourteenth Century, Climatic Change, 34, 91108, 1996.

Remo, J. W. F. and Pinter, N.: Retro-modeling the Middle Mississipi River, J. Hydrol., 337, 421-435, 2007.

Thorndycraft, V., Barriendos, M., Benito, G., Rico, M., and Casas, A.: The catastrophic floods of AD 1617 in Catalonia (northeast Spain) and their climatic context, Hydrol. Sci. J., 51, 899-912, 2006.

Tuset, J.: Reconstrucció de l'aiguat de Santa Tecla en el riu Ondara a Tàrrega a partir de limnimarques i restes de dipòsits decantats. Unpublished Master Thesis, ETSEA, University of Lleida, 224 pp., 2007.

Tuset, J.: Reconstrucció de l'aiguat de Santa Tecla (23 de setembre de 1874) en el riu Sió a partir de documentació històrica, Unpublished Master Thesis, ETSEA, University of Lleida, 40 pp., 2011.

US Army Corps of Engineers (USACE): HEC-RAS River Analysis System: Hydraulic Reference Manual, US Army Corps of Engineers Hydrologic Engineering Center, Davis, CA, 2008.

\section{Historical sources}

Anonymous: La rubina del dissabte passat, Crònica Targarina, 478, (25 October 1930), Tàrrega, 1930.

Arxiu Comarcal de l'Urgell (ACUR): Nota de la rubina de l'any 1615, ACUR, FMT, Llibre d'Actes i Memòries, 1603-1621, p. $1 \mathrm{v}, 1621$. 
Castellà, J. and Miranda, C.: Fuertes riadas en varias comarcas de Cataluña, Un desaparecido en Tàrrega, La Vanguardia, 38.751 (29 October 1989), 44, Barcelona, 1989.

Coma, M. T.: Les inundacions en el terme municipal de Tàrrega, Urtx, 2, 249-259, 1990.

Espinagosa, J., Gonzalvo, G., and Coma, T.: La rubinada de Santa Tecla de 1874 a Tàrrega, Ed. facsímil., Natan Estudis, Ajuntament de Tàrrega, Tàrrega, 110 pp., 1996.

Farré, M. A.: Fenòmens naturals i religiositat a la Tàrrega dels segles XVI-XIX, Urtx, 22, 151-164, 2008.

Iglesies, J.: L'aiguat de Santa Tecla (23 de setembre de 1874), Episodis de la Història no 156, R. Dalmau, Barcelona, 62 pp., 1971.

Parets, M.: De los muchos sucesos dignos de memoria que han ocurrido en Barcelona y en otros lugares de Cataluña (16261660), in: Memorial Histórico Español, edited by: Pujol, C., XXIII, Madrid, 1891.
Salvadó, J.: Memoria de la inundación acaecida en la villa de Tárrega en la madrugada del día 23 de Setiembre del año 1874 con una reseña histórico-crítica de las que tuvieron lugar en la misma villa en 17 de Setiembre de 1644, en 17 de Setiembre de 1783 y en 25 de Agosto de 1842, Establecimiento Tipográfico de Ramírez y Comp., Barcelona, 1875.

Segarra, J. M.: Història de Tàrrega amb els seus costums i tradicions, Museu Comarcal de Tàrrega, Tàrrega, España, Vol. II (Segle XVI-XVIII), 1987.

Vila, M. A.: Catalunya: rius i poblament, Publicacions de l'Abadia de Montserrat, Barcelona (Col. Cavall Bernat, 30), 223 pp., 1998. 